\title{
Güncel Teknolojiler Perspektifinde Kentleşme ve Mimarinin E - Dönüşümü
}

\author{
Fatih Çağatay Baz \\ Osmaniye Korkut Ata Üniversitesi \\ ORCID: 0000-0002-6398-9851
}

Öz

Günümüzde teknoloji kullanımı her alanda hızla ilerleme göstermektedir. Eğitimden sağhı̆̆a, eğlenceden endüstriye insan yaşamını doğrudan teknoloji etkilemektedir. Kent, kentleşme ve mimari alanlarında teknoloji göz ardı edilemeyecek oranda önemlidir. İnsanları kişisel yaşam alanlarıdan, sosyal anlamda toplumun tüm temel ögelerine teknoloji nüfus etmiştir. Teknoloji kavramlarn bilgi ve iletişim araçlarn ile kentlerin ve mimarinin de şekillenmesinde rol oynamaktadır. Akıllı şehirlerin konuşulduğu bugünlerde farklı alanlarda çalışan uzmanların bir araya gelerek kent ve kentleşme alanlarına yoğunlaştıkları görülmektedir. Mühendisliğin farklı dalları ve mimarlık alanının ortaya koyduğu çalışmalar yeni bazı kavramları da bizlere kazandırmaktadır. Kentleşme ve mimaride elektronik dönüşüm olarak adlandırılacak yeni konu başlıkları bu çalışmada ortaya konulmaya çalışılmıştır. Kent, kentleşme ve mimari kavramlarına ışık tutulmak amaçlanmıştır. Aynı zamanda bilişim teknolojilerinin kentleşme - akıllı şehirler uyumuna değinilmiştir. Kent, kentleşme ve mimari konularında elektronik dönüşümün önümüzdeki yillarda ivmelenme göstereceği ortadadır. Bu araştırmanın, yapılacak sonraki çalışmalara yol gösterici olacă̆ı düşünülmektedir.

Anahtar Kelimeler: Güncel teknolojiler, e - dönüşüm, akıllı kent. 


\title{
Urbanization in the Perspective of Contemporary Technologies and E - Transformation of Architecture
} $*$

\author{
Fatih Çağatay Baz \\ Osmaniye Korkut Ata University \\ ORCID: 0000-0002-6398-9851
}

\begin{abstract}
Today, the use of technology is progressing rapidly in every field. Technology directly affects human life from education to health, from entertainment to industry. In the city, urbanization and architecture, technology is so important that it cannot be ignored. Technology has populated all the basic elements of society from the personal living spaces of the people. Technology concepts also play a role in shaping cities and architecture with information and communication tools. Nowadays, when smart cities are discussed, it is seen that experts working in different fields come together and concentrate on urban and urbanization areas. The different branches of engineering and the studies put forward by the field of architecture give us some new concepts. In this study, new topics which will be called as electronic transformation in urbanization and architecture are tried to be put forward. It is aimed to shed light on the concepts of city, urbanization and architecture. At the same time, the adaptation of information technologies to urbanization - smart cities is mentioned. It is clear that electronic transformation in urban, urbanization and architecture will accelerate in the coming years. It is thought that this research will guide the future studies.
\end{abstract}

Keywords: Current technologies, $e-$ conversion, smart city. 


\section{Giriș}

Teknolojideki gelişmeler insanları ilgilendiren birçok alanda değişiklikleri beraberinde getirmiştir. Özellikle bilgisayar ve iletişim teknolojilerindeki gelişmelerin paralelinde toplumlar endüstriden eğitime, eğlenceden ulaşıma kadar farklı alanlarda yeniliklerle karşılaşmaktadır. Teknoloji yaşamımızın tüm alanlarını gün geçtikçe kuşatır hale gelmiştir. Şüphesiz bu dönüşümden kentler de nasibini almaktadır.

Kentler insanların bir araya gelerek yaşadıkları, nüfusun çoğunun ticaret, sanayi veya hizmet alanı gibi farklı iş kollarında çalıştığı yerleşim alanlarıdır. Kentler dinamik yapıları gereği büyümeye, üretim ve yeniliklere her zaman açıktır. Dünya nüfusunun yaklaşık yüzde $55^{\prime}$ i şehirlerde yaşamakta ve toplam gayrisafi katma değerin yaklaşık yüzde $80^{\prime}$ i de kentlerde üretilmektedir. Velibeyoğlu (2016) Avrupa' da kentlerde yaşayanların oranının yüzde 80 olduğunu ve 2050 yılına gelindiğinde dünya nüfusunun yaklaşık yüzde 70' inin kentlerde yaşayacağının öngörüldüğünü ifade etmektedir. $\mathrm{Bu}$ anlamda kentlerde yaşanacak yoğunluğun insan yaşamını farklı alanlar da etkilemesi kaçınılmazdır.

Bugün gelinen noktada Elvan (2017)' a göre; üretim, yenilik ve teknoloji odaklı gelişen kentlerde, verimliliği arttırmak ve yaşam kalitesini geliştirmek üzere birtakım arayışlara girilmektedir. Bu arayışlar; akıllı arayışlar ve uygulamalar yolunda ilerlemektedir. Tabi ki büyük kentlerde daha çok karşılaşılan birtakım sorunlar, başta ekonomik ve sosyal hayatı olumsuz etkilemektedir. Bu sorunların başında hiç şüphesiz hızlı nüfus artışı gelmektedir.

Bilişim teknolojilerinde kullanılan yenilikler ile akıllı şehirlerin kurgulanması ile kentsel hizmet sunumunda yeni yaklaşımlar ortaya çıkmıştır (Albino, Berardi ve Dangelico, 2013). Güncel teknoloji yaklaşımları insan yaşamına dolayısı ile insan yaşam alanlarına nüfuz etmiştir. Bu anlamda kent, kentleşme ve mimari alanlarında teknolojinin geldiği güncel tüm gelişmeleri görmek mümkündür. Teknolojinin faydalı kullanımı ile kentlerde yaşanabilecek sorunları çözmek birçok araştırmanın konusu olmaktadır.

\section{Kent ve kentleşme kavramları}

Kentler genel bir ifade ile tarihsel sürekliliğin ürünleridir. Kentler, tarihsel süreçte, dünyadaki yaşamsal kırılmalarda rol alan önemli aktörlerden bi- 
risidir, belki de en önemlisidir. Yaşanılan kentlerin kentsel ve mimari açıdan yapıları bu sürekliliğin içinde yer alan şekilleri, estetik anlamda yorumlanışları ve teknolojik imkanların somut yansıması olarak ifade edilen oluşum-değişim-dönüşüm sonucu yeni halini almaktadır (Akbalık, 2017; Altınöz, 2010). Burada ifade edilen teknolojik imkanların somut bir şekilde yansıması, kentlere yeni bir şekil kazandırmada aktif rol almaktadır.

Son zamanlarda kent kavramında ve kentsel mekanlarda biçimsel ve aynı zamanda işlevsel değişimler meydana gelmiştir. Bu yüzden kent kavramının içeriğinde de değişiklik meydana gelmiştir. Kent kavramının tanımlanmasında tarih, sosyoloji, ekoloji ve coğrafya gibi çok sayıda bilim alanının incelenmesiyle farklı yaklaşımlar da sergilenmektedir (Topal, 2004). Bunların yanı sıra finansal kurumlar, eğitim ve sağlık kurumları, birçok farklı alanda hizmet veren şirketler kentlerde önem kazanmıştır. Bu bahsedilen kurumlar için teknolojideki yenilikler, özellikle internet ve ağ ortamı, çok önemli rol oynamaktadır (Çakır, 2019).

Kentlerin değişen insanla birlikte değişim göstermeleri de kaçınılmaz bir hal almaktadır. Güleç Solak (2017)' a göre kentsel mekanlar, kentlerin kamusal anlamda benliklerini ve kimliklerini oluşturmaktadır. Ayrıca, kentlerde yaşayanların kimliklerini ve kişiliklerini şekillendirmelerinin yanında medeniyetlerin oluşumunu karşımıza çıkarmaktadır. Fiziksel, zamansal, sosyolojik ve psikolojik yönleri ile insan her zaman kentlerin önemli faktörü olmuştur (Köseoğlu, 2011). Bu anlamda kentler insanları insanlar kentleri etkilemektedir, hatta değiştirmektedir ifadesini kullanabiliriz.

Kent mekanlarının kurgulanmasında, bilişim ve teknolojinin avantajlarından faydalanmak gerekmektedir. İkamet yerleri, çalışma alanları, yaşam alanları ve eğlence alanları yapılandırılırken mimarinin insanların ortak paydalarına hitap edebilir nitelikte olması gerekmektedir. Kentler farklılıkları gözeten, farklı kültürleri öğretmede uyumlu olmalıdır. Bu gerekçelerden ötürü mimari ve kentleşmenin üzerine büyük görev düşmektedir (Karakurt, 2006).

\section{Bilişim teknolojileri ve kent - kentleşme uyumu}

Dünyada nüfusun hılı şekilde artması beraberinde kentlerin planlamasında sorunlara sebep olmuştur. Plansız büyüme ve plansız yayılma sebeplerinden insanlığın bu anlamda geleceğine ilgi artmıştır. Kent planc1ları ve bu konuda çalışan kişilerce kentleşmedeki problemleri önlemenin 
yolları aranmaktadır (Aktuğlu Aktan, 2012). Bu konuda bilişim teknolojilerinden faydalanmak kent ve kentleşme konularında çalışanlara destek olmaktadır.

Günümüzde bilgisayar mühendisleri ve tasarım işi üzerine çalışanlar iş birliği içinde hareket etmektedir. Bu iş birliği neticesinde, bilişim teknolojileri desteği ile, kentleşmede mimarinin tasarım süreci yeniden şekillenmektedir (Gezer, 2011). Teknolojinin farklı alanlarda kullanımları kent ve kentleşme alanında güncel başlıkları ilgilendirmektedir. Bu başlıklardan birisi de hiç şüphesiz enerjidir. Son yıllarda farklı alanlarda, farklı türlerde enerji üretimi artış göstermiştir. Bu enerji türlerinin de kent ve kentleşmede kullanımı ortadadır. Bu enerji türlerinin bazıları; güneş enerjisi, rüzgâr enerjisi, hidrojen enerjisi ve jeotermal enerji gibi enerji türleridir.

Özburak (2016) gelişmekte olan teknolojiyle birlikte mimarinin de enerji sistemleri ile şekillendiğini ifade etmektedir. Enerji sistemlerinin mimarlık ve mühendislik alanlarının disiplinler arası çalışması ile kentleşme ve mimari de verimi arttırdığını belirtmiştir. Ayrıca Yalçıner Ercoşkun ve Karaaslan (2009)' in da belirttiği gibi ekolojik planlama ile de eko - köyler, eko - kentler tasarımdan hayata geçirilmiştir. Yine teknolojik planlamalar ile de teknokent ve akıllı kent - akıllı konut projeleri de tasarlanmaya devam etmektedir.

Teknoloji çağında yaşayan insanlığın, mimari ile teknoloji arasındaki ilişkilerini yeniden gözden geçirmesi gerektiğini Lökçe (2002) ifade etmiştir.

\section{Kentleşmede e - dönüşüm: akıllı şehirler}

Yaşadığımız ortamlar ve mekanların değişimi, yaşam standartlarımız ile aynı oranda ivmelenme göstermektedir. Değişim, dönüşüm ve farklılaşma gibi olgular insan yaşamının da bir parçasını oluşturmaktadır. Ancak değişimin, dönüşüm olgusunun planlı ve aynı zamanda sürdürülebilir olması önemlidir (Semerci ve Alagöz, 2015). Bu anlamda kent ve kentleşmede gerçekleşecek dönüşüm, insan yaşamında önemli bir yer tutmaktadir.

Akıllı şehir kavramı tanımını Terzi ve Ocakçı (2017); “Sürdürülebilir bir yaşam ve kentleşme için teknolojinin kentlere uygulanması" olarak yapmaktadır. Uygulanan teknolojik çözümlerden en çok vurgulananları ise; su yönetimi, temiz ve yenilenebilir enerji, akıllı trafik kontrolü, e-devlet, şehir içi hareketlilik, kablosuz internet erişilebilirliği ve atık yönetimi ile ilgili çözümler olarak belirtmişlerdir. 
Tablo 1. Akıllı şehirler hakkında perspektifler ve ilgili kavramlar (Finger, 2018)

\begin{tabular}{|c|c|}
\hline Akıllı şehirler hakkında perspektifler & İlgili kavramlar \\
\hline $\begin{array}{l}\text { Mühendislerin bakış açısı: Ağ altyapıla- } \\
\text { rının, özellikle de dijital altyapıların ve } \\
\text { dijital teknolojilerin daha yaygın olması }\end{array}$ & $\begin{array}{r}\text { Dijital şehir } \\
\text { Her yerden şehir } \\
\text { Kablolu şehir }\end{array}$ \\
\hline $\begin{array}{l}\text { Ekonomistlerin bakış açısı: İş } \\
\text { dünyasında kentsel ekonomik gelişme, } \\
\text { (özel) girişimcilik ve iş zekası nedeniyle }\end{array}$ & $\begin{array}{r}\text { Girişimci şehir } \\
\text { Akıllı şehir }\end{array}$ \\
\hline $\begin{array}{l}\text { Yenilikçi ekonomistlerin bakış açısı: } \\
\text { Kentsel gelişim odaklı ileri teknoloji ve } \\
\text { yaratıcı (sanat ve tasarım) endüstriler } \\
\text { (akıllı uzmanlık; akıllı teknolojilerde } \\
\text { uzmanlık) }\end{array}$ & $\begin{array}{r}\text { Yenilikçi şehir } \\
\text { Akıllı büyüme şehri } \\
\text { Yaratıcı şehir }\end{array}$ \\
\hline $\begin{array}{l}\text { Kamu yöneticileri perspektifi: Şehirlerin } \\
\text { yönetilme şeklindeki yenilik, yani } \\
\text { BİT'ler sayesinde (örneğin, e-devlet) }\end{array}$ & $\begin{array}{r}\text { Şehri öğrenme } \\
\text { Bilgi şehri }\end{array}$ \\
\hline $\begin{array}{l}\text { Sosyologlar'ın (ve bir dereceye kadar } \\
\text { mimarın) bakış açısı: Bilgi ve iletişim } \\
\text { teknolojileri sayesinde topluluk oluş- } \\
\text { turma (ve paylaşma) }\end{array}$ & Şehirleri paylaşma \\
\hline $\begin{array}{l}\text { İnsan ekolojistlerinin bakış açısı: BİT'ler } \\
\text { sayesinde bir miktar daha gelişmiş, } \\
\text { insan ve ekolojik değerlere dayanan } \\
\text { kolektif bir yaşam alanı olarak şehirler }\end{array}$ & $\begin{array}{r}\text { İnsancll şehir } \\
\text { Sürdürülebilir şehir }\end{array}$ \\
\hline
\end{tabular}

Nath (2018)' a göre akıllı şehirler misyonu, sürdürülebilir kentsel gelişim sağlama yönünde yeni beklentiler ve olumlu düşünceler getirmiştir. Kentleri inşa etmek ve kentleşmenin zorluklarını üstlenmek için uygulamaya yönelik yapılar ve yaklaşımlar benimsenmelidir.

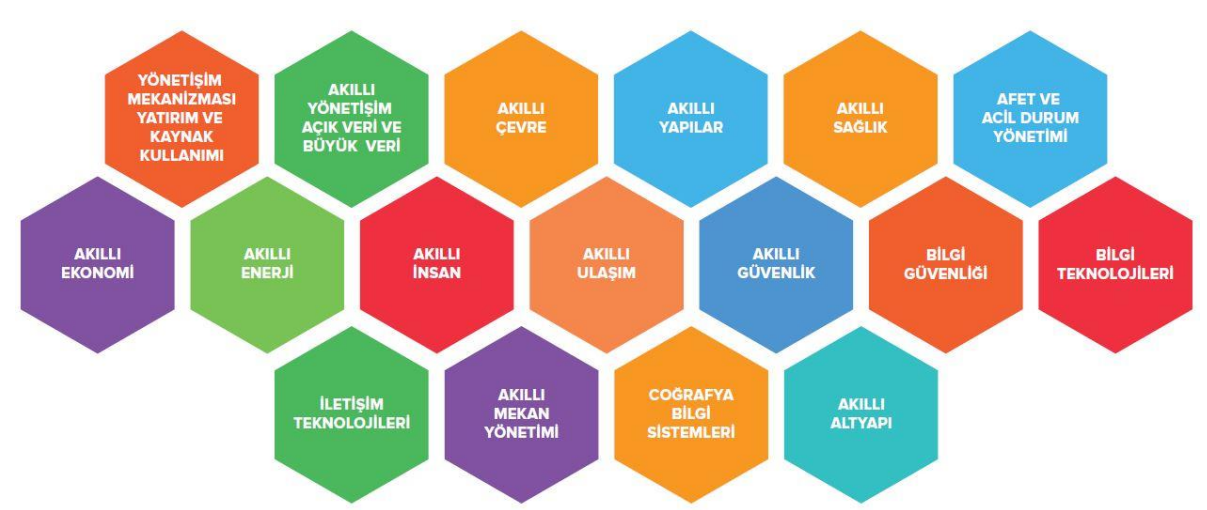

Şekil 1. Akıllı şehir bileşenleri (Çevre ve Şehircilik Bakanlığı, 2019). 
Son yirmi yılda akıllı şehir kavramından bilimsel anlamda oldukça sık söz edilmekte, uluslararası politikalarda giderek daha popüler hale gelmektedir. Akıllı şehir kavramını anlamak için, şehirlerin neden gelecekte stratejik planlarda kilit unsur olarak kabul edildiğini bilmek önemlidir (Albino, Berardi ve Dangelico, 2013). Bilgi toplumunun geldiği noktada kuramsal olarak, yönetişim teorilerinde, bu yeni kentler; dijital kent veya sanal kent, siber kent, akıllı kent, elektronik kent (e - kent) ve bunlara benzer bazı yeni kavramlar ile anılır duruma gelmiştir (Çakır, 2019).

Şekil 1'de Ulusal Akıllı Şehirler Stratejisi ve Eylem Planı kapsamında 17 farklı bileşenden oluşan akıllı şehirler bileşenleri verilmiştir. Bu kapsamda akıllı yönetişim açık veri ve büyük veri bileşeninden coğrafi bilgi sistemlerine kadar farklı alanları bir araya getirecek bilişim teknolojileri akıllı şehirlerde önem arz etmektedir. Polat ve Bilsel (2006)' e göre kenti oluşturan yapıların ve mekanların, aynı zamanda bir bütünlüğe sahip olduğunu ve bunun bir gerçeklik olduğunu unutmamak gerekmektedir.

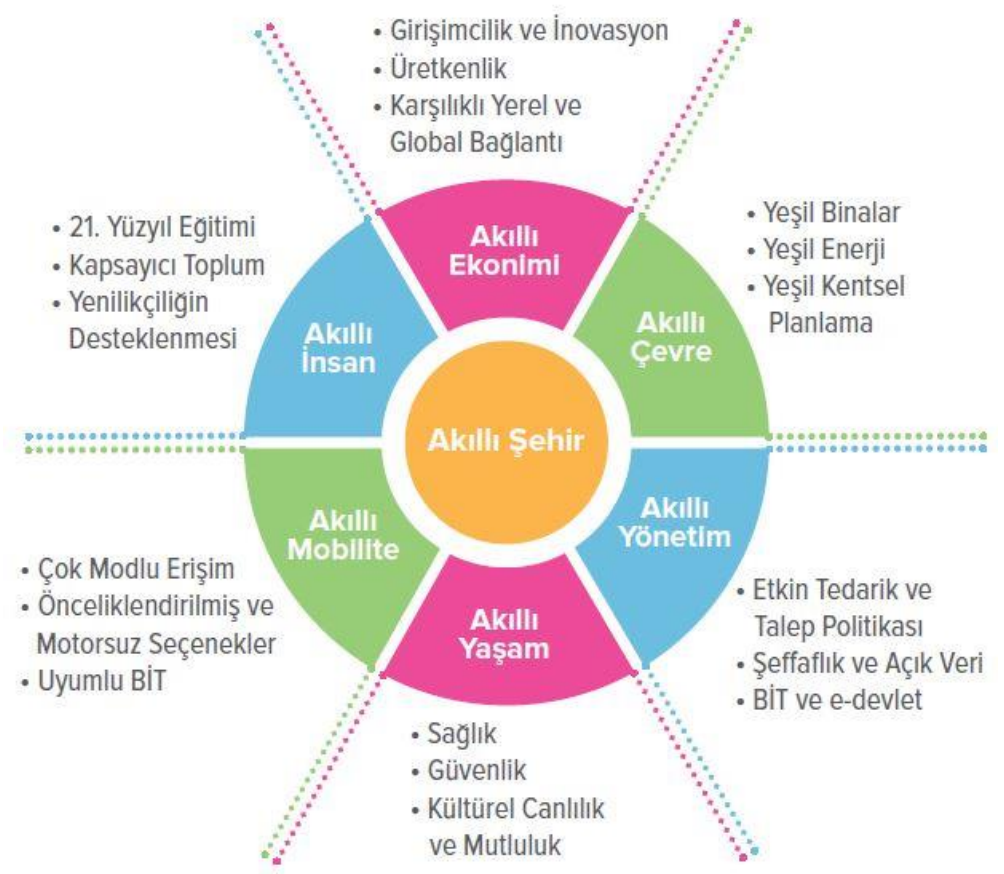

Şekil 2. Akıllı şehir alanları (Çevre ve Şehircilik Bakanlı̆̆ı, 2019). 
Akıllı şehirlerin bileşenlerinin yanı sıra, akıllı şehirlerin alanları da mevcuttur. Bu alanlar akıllı insan, akıllı yönetim, akıllı yaşam, akıllı çevre, akıllı mobilite, akıllı ekonomi şeklinde sıralanmaktadır (Çevre ve Şehircilik Bakanlığı, 2019). Akıllı şehir alanlarının birbirleri ile ilişkileri Şekil 2' de verilmektedir.

Kentleşme ve mimari açıdan teknoloji seçimi süreci tasarım aşamasından başlamaktadır. Bu aşamadan itibaren tüm süreçte işbirlikçiler arasinda geri dönütler gerçekleşmeli, kontroller sağlanmalı ve bu sayede teknolojide ilerlemeler olmalıdır (Çırpı ve Sev, 2015).

Akıllı şehirlerin pek çok avantajının yanı sıra birtakım zorlukları da vardır. Bu zorlukları Mohanty, Choppali ve Kougianos (2016) şu şekilde siralamaktadır:

$\checkmark$ Tasarım maliyeti,

$\checkmark$ Operasyonel verimlilik,

$\checkmark$ Karbon salınımı,

$\checkmark$ Kentin büyümesi,

$\checkmark$ Afet esnekliği,

$\checkmark$ İletişimde güvenlik,

$\checkmark$ Bilgi güvenliği,

$\checkmark$ Operasyon maliyetleri,

$\checkmark$ Çevre kirliliğ̈i,

$\checkmark$ Kent sürdürülebilirliği,

$\checkmark$ Sistem hataları,

$\checkmark$ Veri hacmi,

$\checkmark$ Kamu güvenliği.

\section{Ulaşımda yeni teknolojiler}

Kentsel ulaşım hizmetleri konusu, kentte bulunan iş, ev ve insanların sosyo - kültürel faaliyet alanlarını ilgilendiren çok taraflı bir konudur. Ayrıca ulaşım konusunun planlama anlayışı sebebiyle çevresel, iktisadi ve sosyal alanlarda değerlendirilmesi gerekliğini ortadadır (Akbulut, 2016). Ulaşım konusu, karayolu, demiryolu, denizyolu, havayolu, boru hattı gibi türlerinden oluşmaktadır. Bu sistemler bir araya geldiğinde taşımacılık hizmetini sunmaktadır (Deniz, 2016).

Sürdürülebilir anlamda ulaşım için ekonomik, sosyal ve çevresel üç farklı boyuttan söz edilebilir. Bu boyular Şekil 2' de verilmektedir. 
Ekonomik ve

Finansal

Çevresel ve

Ekolojik

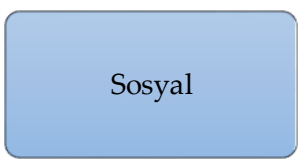

Şekil 2. Sürdürülebilir anlamda ulaşımda kalkınmanın üç boyutu (Kaçıral, 2007).

Son zamanlarda birçok Avrupa ülkesinde kullanılan yeni bir sistem vardır. Bu sistem kentlerde trafikte sürücülerin daha hızlı şekilde yol almalarını sağlamaktadır. Özellikle taksilerin ve kişisel araçların kullanımına sunulan bu sistemde, uydu vasitasılyla araç sürücüleri bilgilendirilmekte ve en kısa güzergahtan en hızlı şekilde ilerlemeleri sağlanmaktadır (Aktuğlu Aktan, 1996).

Kentsel ulaşım alanında şekillenme nüfustaki artış paralelinde gerçekleşmektedir. Ulaşım ve kent biçimi ilişkisinde altyapı sistemleri, ulaşım türleri ve kullanıcılar arasındaki ilişki Şekil 3’ de verilmiştir.

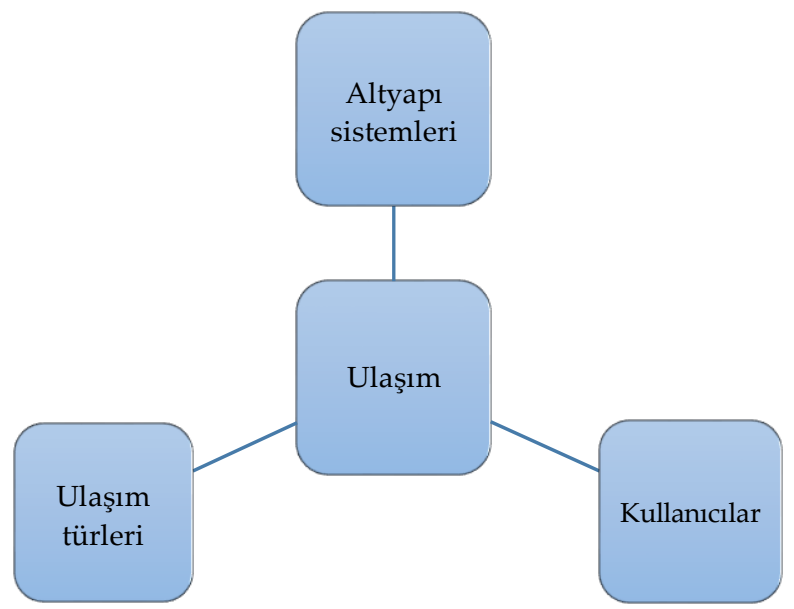

Şekil 3. Ulaşım ve kent biçimi ilişkisi (Özbay, 2018). 


\section{Tartışma ve Sonuç}

Son yıllarda yaşamın her alanında öncelik duruma gelen teknoloji konusu insan yaşam alanlarını doğrudan etkilemektedir. İnsanların kişisel yaşam alanlarından, sosyal anlamda toplumun tüm temel ögelerine kadar teknoloji nüfus etmiştir. Teknoloji kavramları bilgi ve iletişim araçları ile kent ve kentleşmenin de şekillenmesinde rol oynamaktadır. Öyle ki yeni birçok kavramda teknoloji ile etkileşim sonucu kullanıma girmiştir.

Kent ve kentleşmede elektronik dönüşüm olarak adlandırılacak yeni konu başlıkları bu çalışmada ortaya konulmaya çalışılmıştır. Kent, kentleşme ve akıllı şehirler kavramlarına ışık tutulmak amaçlanmıştır. Aynı zamanda bilişim teknolojilerinin kentleşme - mimari uyumuna değinilmiştir. Kent, kentleşme ve mimari konularında elektronik dönüşümün önümüzdeki yıllarda ivmelenme göstereceği ortadadır.

Güncel teknoloji açısından kentleşme ve akıllı şehirler konusu disiplinler arası çalışmaları gerektirmektedir. Akıllı evlerden akıllı şehirlerin tasarlanmasına ve bu tasarımların uygulanmasına kadar mühendisliğin farklı alanlarının bir arada çalışması gerekmektedir. Programlamadan çizim işlemlerine, bunların sahada uygulanmasından sürecin yönetilmesine kadar ki süreçler zor, maliyetli ve yorucudur.

Kentleşme ve mimaride, akıllı şehirlerin tasarlanmasında alanyazında çalışmalar mevcuttur (Akbulut, 2016: Albino, Berardi ve Dangelico, 2013; Mohanty, Choppali ve Kougianos, 2016). Çalışmalar genel olarak kavramsal konuları ele almaktadır. Yapılacak çalışmaların teknoloji kullanımı ve kentleşme mimari alanları ilişkisinde, uygulamaya dönük olması araştırmacılara önerilebilir.

Yapılacak çalışmalarda yönetim bilişim sistemleri konusunda çalışan araştırmacıların, akıllı kent yönetim sistemlerinde öne çıkan uygulamalar ile konuya katkı sağlayacakları düşünülmektedir. Gerçekleştirilecek süreçlerin teknik alanda uzman kişilerce sahada uygulanmasının yanı sıra, iyi planlanması ve yönetilmesi gereken kentleşmenin önemi ortadadır. Ayrıca Türkiye' nin akıllı kent yatırım ve girişimlerini farklı alan ve düzeylerde uygulanmasını teşvik etmeye yönelik yatırım ve girişimleri arttırmalıdır. Bu girişimler kent yönetimi, enerji yönetimi, altyapı ve ulaşım, güvenlik, sağlık ve erişilebilirlik, bilgi erişimi, çevre ve atık yönetimi gibi başlıklarda çeşitlilik göstermelidir. Bu anlamda akıllı kent olma yolunda vizyon sahibi şehirlerden başlanarak planlamalar gerçekleştirilmelidir. 


\title{
Extended Abstract
}

\section{Urbanization in the Perspective of Contemporary Technologies and E - Transformation of Architecture} *

\author{
Fatih Çağatay Baz \\ Osmaniye Korkut Ata University \\ ORCID: 0000-0002-6398-9851
}

Advances in technology have brought some changes in many areas of concern to people. Especially in parallel with the developments in computer and communication technologies, societies face innovations in different fields from industry to education, from entertainment to transportation. Technology has encompassed all areas of our lives day by day. Undoubtedly, this transformation also has its share of cities. Cities are settlements where people come together and where most of the population works in different working areas such as trade, industry or service area. Due to their dynamic structure, cities are always open to growth, production and innovation. About 55 percent of the world's population lives in cities and about 80 percent of total gross value added is produced in cities. At the point reached today; In developing cities focused on production, innovation and technology, a number of quests are made to increase productivity and improve the quality of life. These searches; smart quests and applications are on their way. Of course, some of the problems encountered in big cities have negative effects on economic and social life. Undoubtedly, rapid population growth is one of these problems. With the innovations used in information technologies and the construction of smart cities, new approaches have emerged in the provision of urban services. Current technology approaches have penetrated human life and also human living spaces. In this sense, it is possible to see all current developments in technology, urbanization and architecture. Solving the problems that may occur in cities with the beneficial use of technology is the subject of many

idealkent (c) Kent Araştırmaları Dergisi (Journal of Urban Studies)

http://idealkentdergisi.com

Geliş Tarihi Received Date: 28.06.2019 Kabul Tarihi Accepted Date: 31.08.2019 
researches. Cities are, in general terms, the products of historical continuity. Cities are one of the important actors in the historical process and vital breaks in the world, perhaps the most important. The urban and architectural structures of the inhabited cities take on a new form as a result of the formation-change-transformation which is expressed as the concrete reflection of technological possibilities and their aesthetic interpretations within this continuity. The concrete reflection of the technological possibilities expressed here plays an active role in bringing cities to a new shape. Recently, formal and functional changes have taken place in the concept of the city and in urban spaces. Therefore, the content of the concept of the city has also changed. In the definition of the concept of the city, different approaches are exhibited by examining many scientific fields such as history, sociology, ecology and geography. In addition to these, financial institutions, education and health institutions and companies providing services in many different areas gained importance in the cities. Innovations in technology, especially the Internet and the network, play an important role for these organizations. It is inevitable that cities change with the changing people. Urban spaces constitute public identities and identities of cities. In addition, they not only shape the identities and personalities of the inhabitants of cities, but also the emergence of civilizations. With its physical, temporal, sociological and psychological aspects, man has always been an important factor in cities. In this sense, we can say that cities affect people and even people change cities. In the construction of urban spaces, it is necessary to benefit from the advantages of information and technology. The architecture should be able to address the common denominator of the people while the residences, working areas, living spaces and entertainment areas are being structured. Cities should be compatible with teaching different cultures, taking into account differences. Because of these reasons, architecture and urbanization have a great responsibility. The rapid increase of the population in the world has caused problems in the planning of cities. Due to unplanned growth and unplanned expansion, interest in the future of humanity has increased. Urban planners and people working in this field are looking for ways to prevent problems in urbanization. Utilizing information technologies in this regard supports employees in urban and urbanization issues. Today, computer engineers and design professionals work in collaboration. As a result of this cooperation, the design process of architecture is 
being reshaped in urbanization with the support of information technologies. The use of technology in different areas concerns the current topics in urban and urbanization. One of these titles is undoubtedly energy. In recent years, different types of energy production in different areas has increased. The use of these energy types in urbanization and urbanization is obvious. Some of these types of energy; solar energy, wind energy, hydrogen energy and geothermal energy. Along with the developing technology, architecture is also shaped by energy systems. With ecological planning, eco - villages and eco - cities have been implemented from design. Technological planning and smart city - smart housing projects continue to be designed with technological planning. Humanity living in the age of technology should reconsider the relationship between architecture and technology. In this study, new topics that will be called electronic transformation in urban and urbanization have been tried to be put forward. It is aimed to shed light on the concepts of city, urbanization and smart cities. At the same time, urbanization - architectural harmony of information technologies are mentioned. It is clear that electronic transformation in urban, urbanization and architecture will accelerate in the coming years. In terms of current technology, urbanization and smart cities require interdisciplinary studies. Different areas of engineering need to work together, from smart homes to the design and implementation of smart cities. From programming to drawing operations, on-site implementation to process management, the processes are difficult, costly and tiring. In urbanization and architecture, there are studies in the field of designing smart cities. The studies deal with conceptual issues in general. It may be suggested to the researchers that the studies to be conducted should be practical oriented in relation to the use of technology and urbanization architectural areas. It is thought that the researchers working in the field of management information systems will contribute to the issue with the prominent applications in smart city management systems. Besides the implementation of the processes to be carried out by experts in the field, the importance of urbanization that needs to be well planned and managed is obvious. In addition, Turkey 's different areas of smart city initiatives and investments and should increase investment and initiatives to promote the implementation level. These initiatives should be diversified in areas such as urban management, energy management, infrastructure and transport, security, health and accessibility, information access, environment and waste management. In this sense, planning 
should be realized by starting from the cities with vision in order to become a smart city.

\section{Kaynakça/References}

Akbalık, E. (2017). Kent, mimarlık ve kimlik üretimi üzerine: ylldızlar ve ikonlar. Mimar.ist. 17 (59). $32-37$.

Akbulut, F. (2016). Kentsel ulaşım hizmetlerinin planlanması ve yönetiminde sürdürülebilir politika önerileri. Kastamonu Üniversitesi İktisadi ve İdari Bilimler Fakültesi Dergisi. 11, 336 - 355.

Aktuğlu-Aktan, E. Ö. (1996). Ulaşımda yeni teknolojiler ve uygulamaların kent biçimine (olası) yansiması. http://www.imo.org.tr/resimler/ekutuphane/pdf/3193.pdf

Aktuğlu Aktan, E. Ö. (2012). İdeal ve ütopik kent modellerine ulaşım bağlamında biçimsel yaklaşımlar. İdealkent Dergisi. 5, 68 - 103.

Albino, V., Berardi, U., ve Dangelico, R. M. (2013). Smart cities: definitions, dimensions, and performance. International Forum on Knowledge Asset Dynamics. 1723 1738.

Altınöz, A. G. B. (2010). Tarihi dokuda "yeni" nin inşası. Ege Mimarlı. 4, 18 - 26.

Çevre ve Şehircilik Bakanlığı (2019). Akıllı şehirler. Beyaz Bülteni. 1 - 132. https://webdosya.csb.gov.tr/db/cbs/menu/akillisehirlerkitap_20190311022214_20190313032959.pdf

Çırpı, M. E., ve Sev, A. (2015). Geleceğin sürdürülebilir yüksek yapıları için teknoloji transferi. 2nd International Sustainable Buildings Symposium. Ankara.

Deniz, T. (2016). Türkiye' de ulaşım sektöründe yaşanan değişimler ve mevcut durum. Eastern Geographical Review. 36, 135 - 156.

Gezer, H. (2011). Malzemenin gizil güçlerinin mimariye katkısı. İstanbul Ticaret Üniversitesi Fen Bilimleri Dergisi. 10 (20), 97 - 118.

Güleç Solak, S. (2017). Mekân - kimlik etkileşimi: kavramsal ve kuramsal bir bakış. Manas Sosyal Araştırmalar Dergisi. 6 (1). 13 - 37.

Elvan, L. (2017). Akıllı şehirler lüks değil ihtiyaç. Dosya: Akıllı Şehirler içinde (s. 6-10). İTÜ Vakfı Dergisi.

Finger, M. (2018). Smart city - hype and / or reality? Innovative governance of large urban systems. 4 (1), $2-6$.

Kaçıral, S. (2007). Ankara ulaşım politikalarında sürdürülebilirlik: Batıkent-Kızılay metrosunun sosyal boyutuyla değerlendirilmesi. Yüksek Lisans Tezi, Gazi Üniversitesi Fen Bilimleri Enstitüsü.

Karakurt, E. (2006). Kentsel mekânı düzenleme önerileri: modern kent planlama anlayışı ve postmodern kent planlama anlayısıı. Erciyes Üniversitesi İktisadi ve İdari Bilimler Fakültesi Dergisi. 26, 1- 25.

Köseoğlu, E. (2011). Kent mekanına ilişkin kuramsal bakışlar: Rob Krier, Christopher Alexander ve Bill Hillier. İdealkent Dergisi. 5, 96-111. 
Lökçe, S. (2002). Mimarlık eğitim programları: mimari tasarım ve teknoloji ile bütünleşme. Gazi Üniversitesi Mühendislik Mimarlık Fakültesi Dergisi. 17 (3), 1 - 16.

Mohanty, S. P., Choppali, U., ve Kougianos, E. (2016). Everything you wanted to know about smart cities. IEEE Consumer Electronics Magazine. 5 (3), 60 - 70.

Nath, A. (2018). Smart cities mission in India: analysing the implementation mechanism and its impact on urban governance. Innovative governance of large urban systems. 4 (1), $17-21$.

Özbay, K. (2018). Ulaşım yatırımları ve kentsel mekân ilişkisi. Kent kültürü ve yönetimi hakemli elektronik dergisi. 11 (3). 367 - 373.

Özburak, Ç. (2016). Mimari yaklaşımda binaya entegre (bütünleşik) yenilenebilir enerji kaynakları kullanımının kent kimliğine olan etkileri. Uluslararası Sürdürülebilir Yapılı Çevre Konferansı. İstanbul.

Polat, E., ve Bilsel, S. G. (2006). Mimarinin ve kentin birlikte planlanmasında farklılaşan kavramlar üzerine. Planlama Dergisi, 4, $57-67$.

Semerci, F., ve Alagöz, M. (2015). Değişen kentler ve sürdürülebilirlik: Konya kenti örneği. 2nd International Sustainable Building Symposium. Mayıs, Ankara. 582 587.

Terzi, F., ve Ocakçı, M. (2017). Kentlerin geleceği: akıllı kentler. İTü Vakfı Dergisi, 77, 10-13.

Topal, A. K. (2004). Kavramsal olarak kent nedir ve Türkiye' de kent neresidir? Dokuz Eylül Üniversitesi Sosyal Bilimler Enstitüsü Dergisi, 6 (1). 276 - 294.

Velibeyoğlu, K. (2016). Akıllı kentler: vaatler ve ötesi. Yenilikçi Sürdürülebilir Gelişme Stratejileri Bağlamında Türkiye Ekonomisinin Geleceğine Yönelik Çözüm Arayışları.

Yalçıner Ercoşkun, Ö., ve Karaaslan, Ş. (2009). Geleceğin ekolojik ve teknolojik kentleri. Megaron Dergisi, 3 (3), 283 - 296.

\section{Fatih Çağatay Baz}

Osmaniye Korkut Ata Üniversitesi Öğretim Üyesi Fatih Çağatay Baz, 1984 yılında Adana'da doğdu. Çukurova Üniversitesi Bilgisayar ve Öğretim Teknolojileri Eğitimi alanında Lisans, ardından aynı üniversitede Yüksek Lisans eğitimini tamamladı. Doktora çalışmasını Mustafa Kemal Üniversitesi Enformatik Anabilim dalında alanında tamamlamıştır. Fatih Çağatay Baz Adana Bilim ve Teknoloji Üniversitesi ve Osmaniye Korkut Ata Üniversitesinde akademik ve idari görevlerde bulunmuştur. Fatih Çağatay Baz Yönetim Bilişim Sistemleri alanında akademik çalışmalarını sürdürmektedir. Çalışma alanlarını uzaktan eğitim, web tabanlı öğrenme ve güncel bilişim teknolojileri konuları oluşturmaktadır. Uluslararası ve ulusal birçok esere sahip olan Fatih Çağatay Baz evli ve iki çocuk babasıdır.

Fatih Çağatay Baz who is an assistant professor at Osmaniye Korkut Ata University was born in Adana in 1984. He completed his undergraduate degree in Computer Educational and Instructional Technology in Cukurova University and then his master's degree in the same university. He completed his $\mathrm{PhD}$ in 
Informatics at Mustafa Kemal University. Fatih Çağatay Baz held academic and administrative positions at Adana Science and Technology University and Osmaniye Korkut Ata University. Fatih Çağatay Baz continues his academic studies in the field of Management Information Systems. His research interests include distance education, web-based learning and current information technologies. Fatih Çağatay Baz is married and has two children.

E-mail: fatihcagataybaz@osmaniye.edu.tr 